\title{
WSZECHMOC I JEJ GRANICE UWAGI O KONCEPCJI BOŻEJ WSZECHMOCY RYSZARDA KLESZCZA
}

Profesor Ryszard Kleszcz jest zwolennikiem stosowania kryteriów racjonalnych $w$ myśleniu filozoficznym ${ }^{1}$. Oznacza to, że preferuje sposoby filozofowania oparte raczej na logicznej analizie niż na wizji czy intuicyjnym wglądzie. Nie może zatem dziwić, że mottem jego filozofowania jest myśl Jana Łukasiewicza głosząca, że „podstawą myślenia racjonalnego jest logika". Określając specyfikę racjonalności filozoficznej, Kleszcz wymienia trzy kryteria: 1) przestrzeganie ścisłości lub jasności językowej; 2) przestrzeganie wymogów logiki; 3) respektowanie postulatu uzasadniania. Pierwsze sprowadza się do nadawania językowi wypowiedzi filozoficznej takiej ścisłości i precyzji, która eliminuje wyrażenia niejasne, wieloznaczne, mgliste lub chwiejne: język charakteryzujący się wysokim stopniem ścisłości pozwala na prowadzenie dyskursu noszącego znamiona racjonalności i obiektywności, które są konieczne dla uprawiania filozofii. Wiąże się to z postulatem formułowania przekonań $\mathrm{w}$ taki sposób, który efektywnie eliminuje sprzeczności logiczne. I wreszcie, skoro jakiś system przekonań ma być uznany za racjonalny, to musi spełniać postulat uzasadniania polegający na dostarczeniu odpowiednich racji, które w sposób spójny pozwalają argumentować w obronie wyznawanego stanowiska.

Takie określenie warunków racjonalności filozoficznej sytuuje Kleszcza w tradycji kultywowanej w Polsce przez tych filozofów, którzy nawiązują do dorobku Kazimierza Twardowskiego i innych przedstawicieli Szkoły Lwowsko-Warszawskiej. Zresztą gdy idzie o zapożyczenia z tej tradycji, to Kleszcz nie tylko nigdy się ich nie wypiera, ale i wyraźnie się do nich odwołuje, sytuując się - by tak rzec - w kolejnym pokoleniu uczniów nawiązujących w sposób wyraźny do tradycji filozofowania sformułowanego we Lwowie przez Twardowskiego. W tradycji tej istniała

${ }^{1}$ Por. (Kleszcz 2007, s. 9-31). Por. także (Kleszcz 1998). 
wyraźna tendencja do odróżniania filozofii w sensie ścisłym od szerokiej problematyki egzystencjalno-światopoglądowej, w której przekonania nie mogą być wsparte przez racje i argumenty charakterystyczne dla racjonalności typowo filozoficznej. Do tych przekonań światopoglądowych Twardowski zaliczał również przekonania religijne, a więc wszystkie te dywagacje, które dotyczą pytań o istnienie i naturę Boga i są związane z szeroko rozumianymi rozważaniami metafizycznymi.

W tym kontekście może nieco dziwić, że ktoś nawiązujący wyraźnie do tradycji Szkoły Lwowsko-Warszawskiej podejmuje rozważania z dziedziny już nie tyle nawet teologii naturalnej, ile w wyraźny sposób z teologii filozoficznej, i zadaje pytanie o naturę i granice atrybutów Bożych. Mam tu na myśli dwa teksty napisane w ostatnich latach przez Kleszcza, które są poświęcone analizie atrybutu Bożej wszechmocy². Co prawda teksty te zajmują się analizą pojęcia wszechmocy w kontekście filozoficznym, badając, czy pojęcie wszechmocy jest spójne wewnętrznie i możliwe do racjonalnej obrony. Pozwala to autorowi pozostać na gruncie analiz czysto filozoficznych i nie rozstrzygać, czy istnieje w rzeczywistości taki byt, który jest wyposażony w analizowany atrybut. Filozof bowiem może sprawdzać wewnętrzną spójność jakiegoś atrybutu czy własności bez względu na to, czy jest ona w rzeczywistości aplikowana do jakiegoś bytu, czy nie. Gdyby jednak w drodze filozoficznych analiz okazało się, że pojęcie wszechmocy jest niespójne logicznie (wewnętrznie sprzeczne), to byłaby to wskazówka negatywna, świadcząca o tym, że w rzeczywistości nie istnieje (nie może istnieć) żaden byt, który jest wyposażony w ową cechę.

Definiując wszechmoc, Kleszcz wychodzi od jej absolutnego lub potocznego rozumienia, które przypisuje bytowi wszechmocnemu możliwość uczynienia wszystkiego, czego ten byt tylko zechce, czyli możliwość spowodowania zaistnienia dowolnego stanu rzeczy (byt taki może zmieniać zarówno prawa rządzące światem, jak i prawa logiki i matematyki). Oczywiście od razu stwierdza, że w tradycji chrześcijańskiego teizmu nie było zgody na tak szeroką definicję i wskazywano, że wszechmoc mogą ograniczać problemy natury logicznej oraz natury moralnej (pozalogicznej). Należy jednak wskazać, że dla teizmu pewnym problemem jest wskazywanie granic Bożej wszechmocy, gdyż jeśli ktoś chce twierdzić, że Bóg jest nieskończony, a Jego moc jest proporcjonalna do Jego bytu, to musi przyznać, że także Jego moc jest nieskończona, a więc niczym nieograniczona. Co prawda teiści nigdy nie przyjmowali, że Bóg może zrobić absolutnie wszystko, ale jeśli chodzi o rzeczywisty zakres wszechmocy, pojawiało się wiele kontrowersji. Święty Augustyn twierdził, że Bóg może zrobić wszystko, co chce, natomiast św. Tomasz uważał,

${ }^{2}$ Por. (Kleszcz 2012; 2015). 
że Bóg może zrobić wszystko to, co jest możliwe, a niekiedy nawet zawężał tę definicję jedynie do tego, co jest logicznie i moralnie możliwe.

Kleszcz, stojąc na stanowisku ścisłego racjonalizmu w analizie natury i atrybutów Boga, zgadza się jedynie z ostatnią z przytoczonych przez nas wstępnych definicji wszechmocy, postulując, że na pojęcie wszechmocy Bożej winno się nałożyć dwa rodzaje ograniczeń:

1) dotyczące tego, co gdyby zostało uczynione, byłoby logicznie niemożliwe;

2) dotyczące tego, co jest logicznie możliwe, ale wykonanie tego działania zmieniłoby naturę Boga (powodując np. Jego irracjonalność) (Kleszcz 2012, s. 45; 2015, s. 213).

Celem, jaki stawiam sobie w niniejszym tekście, jest krytyczna lektura obu artykułów Kleszcza poświęconych wszechmocy i próba wskazania pewnych możliwości interpretacyjnych, których sam autor do końca nie wykorzystał, choć niektóre z nich wyraźnie sygnalizował. Idzie mi zatem o pewne dopowiedzenia i rozwinięcia, dla których inspiracje stanowią oba wspomniane teksty o wszechmocy. Uczynię to zwłaszcza w kontekście prowadzonych przez Kleszcza rozważań nad logicznymi i moralnymi ograniczeniami wszechmocy oraz paradoksami generowanymi przez ograniczenia logiczne i moralne.

\section{Problemy logiczne z wszechmocą}

Ryszard Kleszcz zakłada, że Bóg respektuje zasady logiki i nie wykonuje działań sprzecznych. Nie wykonuje zatem działań niemożliwych i nie powoduje zaistnienia sprzecznych ze sobą stanów rzeczy. To ograniczenie nie pozbawia Boga wszechmocy. Wszechmoc nie może być bowiem możliwością uczynienia wszystkiego, co się tylko zechce, możliwością sprawiania dowolnych stanów rzeczy, gdyż Bóg nie może lub nie powinien czynić działań sprzecznych wewnętrznie ani naruszać praw natury. Toteż mylili się wszyscy ci - tacy jak Piotr Damiani, Marcin Luter czy Kartezjusz - którzy uważali, że logika nie ogranicza Boga i może On czynić wszystko, niezależnie od tego, czy rzeczywiście to czyni, czy nie. Skoro bowiem nie istnieje nic, co jest niezależne od Boga (prawa logiki i matematyki, pojęcia prawdy i dobra, prawa natury), to wszystko może lub mogłoby ulec zmianie mocą boskiej decyzji. Pozorna niezależność stworzenia wyraża się w tym, że Bóg mocą swojej pierwotnej decyzji nadał wszystkiemu niezmienny kształt, ale nic nie stoi na przeszkodzie, aby musiał to na zawsze respektować, i bez żadnej trudności może w okresie późniejszym naruszać prawa natury lub zawieszać zasadę niesprzeczności. 
Wbrew temu stanowisku Kleszcz utrzymuje, że Bóg nie generuje sprzeczności, gdyż Jego moc ma taki zakres, który jest możliwy logicznie do posiadania. Podąża w tym za św. Tomaszem, który uważał, że Bóg właśnie dlatego jest wszechmocny, że może czynić wszystko to, co jest możliwe. Pewnych rzeczy nie może jednak uczynić, gdyż nie może czynić niczego, co pociąga sprzeczność (np. sprawić, żeby jakaś rzecz istniała i nie istniała). Zasady logiki i matematyki wynikają zdaniem św. Tomasza z formalnych zasad rzeczy, od których zależy istota rzeczy, więc Bóg nie może czynić niczego przeciwstawnego wobec tych zasad, bo to wprowadzałoby sprzeczność do rzeczywistości.

Skoro Bóg to Istota respektująca prawa logiki, to - zdaniem Kleszcza - Jego wszechmoc musi wyłączać działania logicznie sprzeczne i ograniczać się tylko do tego, co logicznie możliwe. Działanie logicznie niemożliwe nie tylko nie może być wykonane, lecz nie jest ono w ogóle spójnym działaniem. Takie stanowisko prowadzi Kleszcza do opowiedzenia się za definicją wszechmocy, którą - za Richardem Swinburne'em - formułuje $\mathrm{w}$ wersji temporalistycznej i eternalistycznej. Jeżeli Bóg istnieje w czasie, to Jego wszechmoc podpada pod następującą definicję: „Istota wszechmocna w czasie $t$, to taka, która jest w stanie sprawiać każdy, dostępny dla niej, logicznie możliwy, przygodny stan rzeczy po t" (Kleszcz 2012, s. 44). Natomiast jeżeli Bóg jest istotą wieczną w sensie pozaczasowym, to definicja Jego wszechmocy będzie brzmiała następująco: „Istota wszechmocna to taka, która jest w stanie sprawiać każdy, dostępny dla niej, logicznie możliwy, przygodny stan rzeczy" (Kleszcz 2012, s. 45). W obu przypadkach zachowany jest racjonalistyczny rdzeń, który pozwala bytowi wszechmocnemu na wykonanie tylko takich działań lub stwarzanie tylko takich stanów rzeczy, które są logicznie możliwe.

Kleszcz dostrzega dwie trudności, które mogłyby w jakiś sposób naruszyć powyższe definicje, aczkolwiek do obu odnosi się ze znacznym sceptycyzmem. Pierwsza sugeruje, że możliwość metafizyczna jest szersza niż możliwość logiczna, co prowadzi do wniosku, że przynajmniej czasami to, co byłoby metafizycznie możliwe, mogłoby okazywać się logicznie niemożliwe. Stanowisko to wiąże się jednak z dodatkowymi założeniami postulującymi, iż reguły logiki nie odbijają w istotny sposób zasad ontologii świata, co dla Kleszcza wydaje się jeśli nawet nie całkiem niedorzeczne, to co najmniej bardzo wątpliwe. Można jednak w tej kwestii odwołać się do innego rozwiązania, dobrze znanego w scholastyce, które wprowadzała rozróżnienie pomiędzy mocą absolutną (potentia absoluta) i mocą uporządkowaną (potentia ordinata) ${ }^{3}$. Dystynkcja ta sugerowała, że w jednej co do natury mocy Bożej są niejako dwa aspekty, odnoszące się

\footnotetext{
${ }^{3}$ Por. (Paluch 2008, s. 385-390).
} 
z jednej strony do tego, co Bóg może zrobić w sensie absolutnym, a z drugiej do tego, co rzeczywiście zrobił w stworzonym przez siebie świecie. Ta pierwsza moc jest czystą możliwością, która wskazuje na to, że moc Boża jest większa w znaczeniu absolutnym od tej mocy, która została przez Boga rzeczywiście urzeczywistniona. Sama dystynkcja służyła jako bardzo subtelne narzędzie do obrony przed zarzutami, że wszechmoc Boża posiada różnego rodzaju ograniczenia. Można było bowiem utrzymywać, że Bóg dzięki działaniu poprzez moc uporządkowaną respektuje prawa natury i zasady logiki, gdyż Jego zamysłem było, aby w taki sposób Jego moc przejawiała się w stworzonym świecie. Zarazem jednak nadal można sądzić, że wszechmoc Boża nie wyczerpuje się całkowicie w mocy uporządkowanej i ta strona mocy Bożej, która nie przejawia się w stworzeniu, może potencjalnie mieć taki charakter, że gdyby zechciała się przejawić, to rozsadziłaby nawet zasadę niesprzeczności. Moc absolutna jest w pewnym sensie konstruktem teoretycznym, który nie przejawia się w świecie i służy wyłącznie do podkreślenia transcendentnego charakteru atrybutu Bożej wszechmocy. Kleszcz z jakichś powodów nie odwołuje się w swoich wywodach do tej dystynkcji, choć wydaje się ona bardzo użyteczna przy określeniu racjonalnych granic wszechmocy. Być może niechęć do jej użycia jest spowodowana tą samą intuicja którą miał św. Tomasz - równie niechętnie się do tej dystynkcji odwołujący - który dostrzegał w niej pewne niebezpieczeństwo sugerujące, jakoby w absolutnej mocy Boga była możliwość działań wewnętrznie sprzecznych, a tylko wybór określonego rodzaju świata, w którym owe sprzeczności nie występują powstrzymywał Boga od takich działań.

Druga trudność sygnalizowana przez Kleszcza wskazuje, że skoro prawa logiki wiążą Boga, to stanowią one coś zewnętrznego wobec Niego, czemu powinien się podporządkować. Powstaje zatem pytanie: jaki w rzeczywistości jest stosunek Boga do praw logiki? Problem ten jest bardzo trudny i stał się on współcześnie powodem bardzo ożywionej dyskusji filozoficznej na gruncie filozofii analitycznej, której inicjatorem był Alvin Plantinga ${ }^{4}$. Uważał on, że poważny problem dla Boga stanowi istnienie przedmiotów abstrakcyjnych - cały platoński panteon uniwersaliów, własności, rodzajów, sądów, liczb, zbiorów, stanów rzeczy i możliwych światów. W sposób naturalny myślimy bowiem o tych rzeczach jako odwiecznych (everlasting), niemających początku i końca, czyli istniejących zawsze. Przedmioty abstrakcyjne wydają się koniecznymi cechami rzeczywistości, czyli ich nieistnienie wydaje się niemożliwe. Przygodne rzeczy mogą nie istnieć, ale w kwestii własności, sądów, liczb i stanów rzeczy ich nie istnienie jest niemożliwe. Powstaje zatem pytanie

${ }^{4}$ Por. (Plantinga 1980). 
o to, jaki jest stosunek i odniesienie tych obiektów abstrakcyjnych do Boga. Skoro istnieją one z konieczności, to są niezależne od Boga, a więc Bóg nie ma nad nimi kontroli. Narusza to jednak w sposób wyraźny suwerenność i aseiczność Boga. Kleszcz nie odnosi się do debaty zainicjowanej przez Plantingę, lecz przywołuje polskie rozwiązanie tego problemu, sformułowane jeszcze przed II wojną światową przez Łukasiewicza. W artykułach Logistyka a filozofia oraz $W$ obronie logisty $k i^{5}$ utrzymuje on, że prawa logiki są niezmienne, gdyż są identyczne z myślami zawartymi w umyśle Bożym. Gdyby zostały przez Boga stworzone lub istniały w sposób całkowicie autonomiczny, to nie dawałyby pełnej gwarancji swej absolutnej niezmienności i traciłyby status gwaranta podstaw racjonalności. Łukasiewicz dodawał jednak, że racjonalność Boża jest szersza od ludzkiej, gdyż Bóg dysponuje najszerszym możliwym systemem logiki, natomiast człowiek dysponuje tylko minimalną komponentą racjonalności. Pozwalało to na utrzymanie pewnego marginesu przy ocenie działań Bożych, które w pewnych okolicznościach mogłyby wydawać się człowiekowi nie do końca racjonalne. Jednak nawet ta szersza racjonalność, w której granicach działa Bóg, dopuszcza tylko takie działania, co do których możemy przyjąć najszersze kryteria racjonalności. Eliminuje ona zatem wszystkie działania, które są logicznie sprzeczne, uznając, że są one niemożliwe do uczynienia nawet dla Boga. Wydaje się, że Kleszcz również skłania się do tego przekonania i sądzi, że racjonalność przynależna Bogu jest najszerszą możliwą racjonalnościa, która nie jest tak restryktywna jak racjonalność ludzka. Dodaje jednak, że racjonalność Boga, pomimo tego, że jest racjonalnością znacznie poszerzającą pole racjonalności dostępnej człowiekowi, nie jest jednak nigdy nieracjonalna i sprzeczna wewnętrznie.

\section{Paradoks kamienia; zadania trudne dla wszechmocy; testy granic wszechmocy}

Kleszcz ma świadomość, że każde pojęcie wszechmocy powinno być poddane próbie $\mathrm{w}$ celu sprawdzenia, czy jest ono poprawnie sformułowane. Najlepszym testem sprawdzającym wewnętrzną spójność pojęcia wszechmocy jest skonfrontowanie jej z różnego rodzaju paradoksami, będącymi swoistym testem możliwości działania wszechmocy. Typowe paradoksy, które można tu wziąć pod uwagę, stawiają przed wszechmocnym Bogiem zadanie stworzenia czegoś, czego następnie nie będzie w stanie kontrolować. Najbardziej popularnym z tej grupy paradoksów jest paradoks kamienia. Formułuje on następującą trudność: czy Bóg może

\footnotetext{
${ }^{5}$ Por. (Łukasiewicz 1961, s. 195-209, 210-219).
} 
stworzyć kamień zbyt ciężki, aby go potem mógł podnieść? Na pierwszy rzut oka wydaje się, że każda odpowiedź narzuca na wszechmoc pewne ograniczenia. Jeżeli bowiem Bóg ma wystarczającą moc do stworzenia takiego kamienia, to wskazujemy tym samym, że nie ma wystarczającej mocy, aby go następnie podnieść. Natomiast jeżeli odpowiemy, że nie ma takiej mocy, aby stworzyć rzeczony kamień, to wskazujemy tym samym, że jest coś, czego Bóg zrobić nie może, a więc również ograniczamy Jego wszechmoc. Kleszcz zauważa, że oba rozwiązania prowadzą do wniosku, że "nie da się mówić spójnie o istnieniu bytu wszechmocnego" (Kleszcz 2015, s. 212). Stwierdza jednak, że sprzeczność jest tutaj pozorna, gdyż w odniesieniu do Boga idea kamienia, którego On nie może podnieść, sama jest wewnętrznie sprzeczna. Powołuje się przy tym na rozwiązanie Swinburne'a, który usiłuje rozwiązać paradoks w kontekście temporalistycznym, choć ostatecznie uważa to rozwiązanie za niezadowalające. Sam jednak nie podejmuje się rozwiązania problemu i nie podaje innych rozstrzygnięć, choć stwierdza, że poprawna koncepcja wszechmocy musi się $\mathrm{z}$ tego typu paradoksami uporać.

Zastanówmy się jednak, w jakim kierunku mogłyby pójść próby rozwiązania paradoksu kamienia przez Kleszcza. Jako zwolennik racjonalizmu, który podchodzi do problemu wszechmocy od strony logicznej spójności, nie mógłby on z pewnością przyjąć rozwiązania kartezjańskiego, którego współczesnym zwolennikiem jest Harry Frankfurt ${ }^{6}$. Autor ten utrzymuje za Kartezjuszem, że Bóg może zrobić absolutnie wszystko, łącznie ze zmianą praw rządzących regułami matematyki i logiki. Może On zatem wykonywać działania, które są dla nas sprzeczne wewnętrznie i absurdalne, jak np. stworzyć górę bez doliny lub uczynić, aby $2+2=5$. Podobnie jest z zadaniem stworzenia takiego kamienia, którego następnie nie może podnieść. Skoro bowiem wszechmocny Bóg może wykonać jedno zadanie sprzeczne wewnętrznie, czyli stworzyć taki kamień, którego nie może podnieść, to może również wykonać drugie sprzeczne wewnętrznie zadanie, czyli podnieść każdy kamień, który uprzednio stworzył. Wszechmocny byt nie potrzebuje bowiem większej mocy do wykonania dwóch niemożliwych logicznie zadań niż jednego takiego zadania. Skoro bowiem nie ograniczają Go żadne reguły logiczności, to może On radzić sobie z takimi zadaniami, z którymi - jak się wydaje - nie może On sobie poradzić.

Innym rozwiązaniem, możliwym, jak się wydaje, dla racjonalistycznego podejścia Kleszcza, byłoby stanowisko rozwijane przez George'a Mavrodesa $^{7}$. Autor ten utrzymuje, że stawianie przed Bogiem zadań

${ }^{6}$ Por. (Frankfurt 2015).

7 Por. (Mavrodes 2015). 
wewnętrznie sprzecznych nie podważa w żadnym razie doktryny wszechmocy Bożej. Jednakże paradoks kamienia można rozumieć jako zadanie, które na pierwszy rzut oka nie pociąga za sobą sprzeczności (nie jest to bowiem zadanie typu „narysuj kwadratowe koło”), aczkolwiek przy bliższej analizie okazuje się zadaniem żądającym w istocie uczynienia rzeczy sprzecznej. Skoro jednak uznamy, że zadanie stworzenia kamienia, którego następnie nie można podnieść, może nie być działaniem sprzecznym, to musimy je rozważyć przy założeniu, że Bóg jest bytem wszechmocnym. Przy takim założeniu widzimy jednak, że sformułowanie „kamień, który nie może być podniesiony przez Tego, którego moc jest wystarczająca do podniesienia wszystkiego" jest formułą sprzeczną wewnętrznie, a więc niemożliwą do sprawienia przez wszechmocnego Boga. Niemożliwość ta nie tylko nie wynika $\mathrm{w}$ żaden sposób $\mathrm{z}$ braku mocy u wszechmocnego Boga, lecz także to właśnie owa wszechmoc sprawia, że taki kamień jest niemożliwy do stworzenia.

Natomiast gdy będziemy upierać się, że zadanie stawiane przed bytem wszechmocnym jest wewnętrznie spójne i opisuje przedmiot możliwy do stworzenia, to możemy odwołać się do rozwiązania naszego paradoksu, które sugeruje C. Wade Savage (1997, s. 183-189). W takim przypadku można odpowiedzieć, że Bóg może stworzyć taki kamień, bo istnienie takiego kamienia jest zgodne $\mathrm{z}$ wszechmocą Bożą. Skoro zatem istnieje możliwość stworzenia takiego kamienia, to nie podważa to w żaden sposób wniosku, że Bóg nie jest wszechmocny. Wydaje się jednak, że istnienie kamienia zbyt ciężkiego, aby można go było następnie podnieść, nakłada na wszechmocnego Boga restrykcje jedynie w odniesieniu do podnoszenia tego kamienia. Ograniczenie to wydaje się jednak pozorne, bo nie można wskazać takiego kamienia, który byłby zbyt ciężki dla wszechmocnego Boga, aby mógł go podnieść. Czy prowadzi to jednak do wniosku, że musimy odrzucić wszechmoc Boga w odniesieniu do stwarzania odpowiednio ciężkich kamieni? Niezupełnie! Jedyne bowiem, co wykluczyliśmy, to istnienie kamienia tak ciężkiego, że wszechmocny Bóg nie mógłby go podnieść. Skoro jednak Bóg może stworzyć kamień o dowolnej (nawet nieskończonej wadze), a następnie ma moc podnoszenia kamieni o dowolnej wadze, to w obu przypadkach Jego moc jest nieograniczona. Okazuje się zatem, że przy bliższej analizie paradoks kamienia w odniesieniu do bytu wszechmocnego okazuje się paradoksem pozornym. Wymaga on bowiem od Boga nie jednego, lecz dwóch zadań, których opisy przestają być wewnętrznie sprzeczne. Upada zatem zarzut, że nie mogą one być wykonane. Okazuje się tym samym, że test kamienia nie nakłada realnych ograniczeń na Bożą wszechmoc.

Kleszcz nie rozwija wprawdzie w ten sposób analizy paradoksu kamienia, ale wydaje się, że jego postulat zachowania racjonalistycznych ram w analizie granic Bożej wszechmocy skłaniałby go raczej do przyjęcia 
umiarkowanego stanowiska Mavrodesa niż radykalnego stanowiska Frankfurta. Można nawet oczekiwać, że nie miałby problemu z akceptacją stanowiska proponowanego przez Savage'a. Wydaje się bowiem, że jeżeli rozpiszemy paradoks kamienia na dwa oddzielne zadania, to możemy powiedzieć, że Bóg jest w stanie oba te zadania po kolei wykonać. Bóg jako byt wszechmocny może stworzyć dowolnie ciężki kamień, w tym również kamień tak ciężki, że nikt (także On sam) nie będzie w stanie go podnieść. Jednak z definicji wszechmocy wynika, że Bóg może wykonać każde spójne logicznie zadanie, a zatem może również podnieść dowolnie ciężki kamień. Toteż Bóg może podnieść każdy kamień, który stworzył. Powtórzmy zatem, że paradoks kamienia stawia przed Bogiem dwa oddzielne zadania, które wszechmocny Bóg, właśnie dlatego, że jest wszechmocny, potrafi kolejno wykonać. Wydaje się, że taka propozycja rozwiązania paradoksu kamienia byłaby dla Kleszcza w pełni możliwa do przyjęcia, gdyż uchyla trudności, które wydaje się stawiać paradoks, a jednocześnie zachowuje racjonalne kryteria w rozumieniu i ocenie możliwości Bożej wszechmocy ${ }^{8}$.

\section{Problemy moralne z wszechmocą}

Obok problemów związanych z ograniczeniem wszechmocy przez spójność logiczną istnieją problemy granic wszechmocy nałożone przez moralność. Wynikają one z tego, że wśród niesprzecznych wewnętrznie działań istnieją takie możliwości, które są w mocy człowieka, a nakładają granice na moc Boga, gdyż pojawiają się w kontekście słabości moralnych. Można sądzić, że Bóg nie może dokonywać czynów, które są nie do zaakceptowania ze względu na Bożą naturę, czyli czynów moralnie złych. Są one wprawdzie logicznie możliwe, ale rodzą konflikt z innymi boskimi atrybutami. Z drugiej strony Bóg jako istota wolna, a nawet, jak ujmuje to Swinburne, „doskonale wolna osoba” (Swinburne 1995, s. 208), winien być wolny w sensie libertariańskim, czyli mieć możliwość czynienia nie tylko tego, co powinien czynić. W związku z tym rodzi się pytanie: czy Bóg jest wolny w sensie libertariańskim, a co za tym idzie, czy Jego decyzje są wyborem z możliwych alternatyw, w tym także alternatyw stawiających Go przed wyborami moralnymi?

Kleszcz definiuje wolność Boga wyraźnie w sensie libertariańskim, ale dodaje, że jako istota wszechwiedząca Bóg z góry wyklucza pewne alternatywy w swoim działaniu. Skoro bowiem nie uważa jakiegoś czynu za coś dobrego, to go nie dokonuje. Bóg ma stosowne i wystarczające racje, aby czynów nagannych moralnie (w także tych wszystkich, które są

${ }^{8}$ Więcej na temat innych rozwiązań paradoksu kamienia por. (Mordarski 2015). 
właściwe bytom cielesnym, a które ograniczałyby boską naturę) nie wykonywać. Poza tym ograniczeniem Bóg nie wykazuje się żadną słabością ani niedoskonałością woli. Sama zaś moc do unikania zła wynika raczej z doskonałości moralnej bytu boskiego oraz Jego absolutnej wolności. Możliwość czynienia zła bowiem wydaje się raczej mocą do zaprzestania działania i istotnego ograniczenia wolności, która wprowadza niedoskonałość w bycie.

Podążając za Swinburne'em, Kleszcz w taki sposób modyfikuje definicję wszechmocy, aby wyłączała ograniczenia płynące ze słabości moralnej bytu. W wersji eternalistycznej, która unika problemów z indeksacją czasowa brzmi ona: „Istota wszechmocna, to taka Istota, która jest w stanie sprawiać każdy logicznie możliwy, przygodny stan rzeczy X, przy założeniu, iż nie jest ona przekonana, że ma nadrzędne racje, by powstrzymać się od sprawiania (aktualizowania) X" (Kleszcz 2015, s. 209). Wszechmoc musi być zatem rozumiana jako posiadanie wszystkich logicznie możliwych mocy, które są logicznie możliwe dla bytu wyposażonego w atrybuty boskie (wszechwiedza, dobroć, niezmienność itp.). Kleszcz w jednoznaczny sposób zgadza się z tym postulatem: „Bóg nie będzie podejmował działań, które prowadziłyby do następstw, powodujących stany rzeczy niezgodne z innymi Jego atrybutami" (Kleszcz 2015,

350 s. 210). Jest przekonany, że te ograniczenia wszechmocy w żadnej mierze nie umniejszają wielkości i świętości Boga będącego przedmiotem czci w religii chrześcijańskiej. Sugeruje nawet, że działania niemoralne podejmowane przez Boga można by uznać za pewien rodzaj aktów nieracjonalnych, które umniejszałyby nie tylko Bożą dobroć, lecz również Bożą wszechwiedzę. Stojąc na stanowisku obrony racjonalizmu w odniesieniu do działań, Boga powiada, że "to, że byt boski nie podejmuje działań, które trzeba by określać jako irracjonalne, nie może pozbawiać Go czci, a wprost przeciwnie, wydaje się bowiem, że to dopuszczanie się działań irracjonalnych byłoby czymś, co Bogu uwłacza" (Kleszcz 2015, s. 211). Toteż dla Kleszcza wszechmoc sprowadza się ostatecznie do wykonywania przez Boga wszystkich działań spójnych logicznie oraz wszystkich tych możliwych działań, w odniesieniu do których dysponuje On silnymi racjami skłaniającymi Go do ich wykonania (Kleszcz 2015, s. 211).

\section{Problem ze zmianą przeszłości}

W taki sposób zreinterpretowane rozumienie wszechmocy natrafia jednak na jeszcze jeden problem: nie bierze pod uwagę możliwości zmiany wcześniejszych stanów rzeczy, czyli takiego działania Boga, które prowadzi do zmiany przeszłości. Skoro bowiem Bóg jest doskonale dobry, 
to czy nie mógłby w taki sposób zmienić przeszłości, aby wymazać z niej wszelką niegodziwość i całe zło? Na pierwszy rzut oka wydaje się to niemożliwe nawet dla bytu wszechmocnego, gdyż generuje sprzeczność logiczną. Sprawienie, aby przeszłość się nie wydarzyła, jest bez wątpienia czynem wewnętrznie sprzecznym. Skoro Polska odzyskała niepodległość w 1918 r., to nie można w 2018 r. sprawić, aby nie odzyskała niepodległości sto lat wcześniej. Zmiana jednego zdarzenia w przeszłości pociąga za sobą konieczność zmiany wszystkich występujących po nim zdarzeń, a co za tym idzie, takiego przemodelowania wszystkich kolejnych skutków, że obecny stan świata będzie zupełnie inny, niż jest.

Kleszcz sugeruje, że zmiana przeszłości pociąga sprzeczność, gdyż musi wiązać się ze zmianą wszystkich kolejnych stanów po tej zmianie następujących oraz równoczesną zmianą wiedzy o przeszłości. Jednak począwszy od Hume'a wielu filozofów zastanawiało się, na ile związek przyczynowo-skutkowy jest związkiem koniecznym oraz czy w pewnych warunkach możemy poprawnie sformułować pojęcie przyczynowości wstecznej. Wiąże się to $\mathrm{w}$ istocie $\mathrm{z}$ pytaniem o to, czy skutek może poprzedzać przyczynę lub czy skutek może być znany, gdy nie wystąpiła jeszcze jego przyczyna ${ }^{9}$. Musimy pamiętać, że w ściśle deterministycznym obrazie świata nie tylko przeszłość, ale również przyszłość jest dokładnie zdeterminowana. W momencie uruchomienia łańcucha procesów deterministycznych bowiem wszystkie skutki, nawet te najdalsze, które wystąpią w odległej przyszłości, są dokładnie znane każdemu, kto posiada całą wiedzę o wszystkich aspektach deterministycznego procesu. Wynika z tego, że nie tylko przeszłość nie może być zmieniona, ale że odnosi się to również do przyszłości. Wprawdzie dla teisty opowiadającego się za modelem eternalistycznym (boecjańskim) nie ma tu żadnego proble$\mathrm{mu}$, bo Bóg w jednym bezczasowym akcie ujmuje cały bieg i całą historię wszechświata, zarówno jego przeszłość i teraźniejszość, jak i przyszłość. Cały czasowy bieg świata jest z perspektywy Bożej jednym aktem stworzenia, w którym moc Boża realizuje się jako pojedyncze działanie, tylko dla przygodnych istot stworzonych rozciągnięte $\mathrm{w}$ czasie i podzielone na przeszłość i przyszłość. W tej perspektywie jakakolwiek zmiana czegokolwiek w ontologii świata nie jest możliwa nie dlatego, że Bóg nie może ingerować $\mathrm{w}$ to, co przeminęło, lecz dlatego, że stwórczy akt Boga jest jedną niezmienna, bezczasową manifestacją Jego mocy, która jest tożsama z samym Bogiem. Wydaje się, że wyraźną świadomość tego miał właśnie Piotr Damiani, który w traktacie $O$ wszechmocy Bożej nie tyle zajmuje się problemem tego, czy Bóg może zmienić przeszłość, ile raczej tego, czy może na nowo „utworzyć" przeszłość. Podstawowe pytanie traktatu:

\footnotetext{
${ }^{9}$ Problem ten dyskutuje szerzej Anthony Kenny (1979, s. 100-109).
} 
„Czy Bóg może przywrócić dziewictwo kobiecie, która je utraciła?" (Damiani 2008, s. 31), nie odnosi się do czysto teoretycznego problemu dotyczącego możliwości działań sprzecznych, lecz nawiązuje do kontekstu moralnego i związanej z tym kontekstem możliwości usunięcia zła, które się wydarzyło. Gdy dostrzeżemy, że problem zmiany przeszłości sformułowany jest nie w języku ontologii, lecz w języku moralności, a nawet - by tak rzec - psychologii, to przestaje on wydawać się tak niedorzeczny. Może wystarczy zmienić tylko pamięć o przykrych rzeczach w przeszłości, nie dokonując żadnych zmian w ontologii świata.

Czy biblijnego stwierdzenia, iż Bóg przy końcu czasów otrze każdą łzę, nie należy rozumieć $\mathrm{w}$ takim sensie, że zmieni On nie tyle przeszłość, ile naszą pamięć i nasze wspomnienia o tych wydarzeniach z przeszłości, które były związane z jakimś doświadczeniem zła i cierpienia? Kleszcz zastanawia się, czy to wystarczy, gdyż wydaje się, że trzeba również spowodować utratę pamięci co do wcześniejszej wiedzy, aby nie było żadnego śladu we wspomnieniach po wcześniejszym jej stanie. Musiałoby to być zatem jakieś nowe „utworzenie” przeszłości, które dokona się w świadomości ludzi zbawionych i będzie związane ze wszystkimi ich wspomnieniami i całą percepcją przeszłości. Dopiero taka przemiana świadomości umożliwiłaby pełne obcowanie z Bogiem wszystkich zbawionych, bez jakichkolwiek przykrych doznań i nieprzyjemnych wspomnień z przeszłości.

Co prawda, nadal istotny wydaje się zarzut, który przytacza Kleszcz - że zmiana przeszłości przez Boga prowadzi do narażenia na szwank Jego prawdomówności. Byłoby tak jednakże tylko w przypadku, gdyby Bóg dowolnie i kapryśnie zmieniał przeszłość w toku historii świata. Natomiast jeżeli zmiana przeszłości nastąpiłaby po zakończeniu historii doczesnej, w chwili rozpoczęcia się czasów eschatologicznych, i miała przy tym charakter związany $\mathrm{z}$ oczyszczeniem pamięci ze wszystkiego zła i cierpienia, które miało miejsce $\mathrm{w}$ toku dziejów, to taka ingerencja Boga w przeszłość nie wywoływałaby negatywnych konotacji w ocenie Jego działania, a nawet mogłaby być uznana za działanie konieczne $\mathrm{z}$ powodów moralnych. Takie działanie można nawet uznać nie tyle za jakiś trik istoty wszechmocnej, ile raczej pewnego rodzaju obowiązek moralny spoczywający na Stwórcy świata, który całkowicie panuje nad swoim stworzeniem i ma wszystko pod swoją opatrznościową kontrolą. Jak sugeruje Kenny, taka możliwość byłaby nawet bardziej prawdopodobna wtedy, gdy zdefiniujemy moc Bożą jako ogół logicznie możliwych mocy, a nie tylko jako moc do wykonywania wszystkich logicznie możliwych działań lub stanów rzeczy ${ }^{10}$.

10 Por. (Kenny 1979, s. 110-117). 
W tym kontekście może zatem dziwić tak łatwa rezygnacja Kleszcza z dosyć użytecznego rozróżnienia - wprowadzonego przez Petera Geacha - na byt wszechmocny (omnipotence) i wszechmogący (almighty) ${ }^{11}$. Uważa nawet, że dyskusja na ten temat angażuje problemy teologiczno-biblijne, które są dosyć złożone dla filozofa, więc na płaszczyźnie filozoficznej powinniśmy się trzymać tradycyjnego pojęcia wszechmocy (omnipotence). Przypomnijmy jednak, że propozycja Geacha sugerowała, że w chrześcijańskim teizmie nie ma potrzeby utrzymywać, iż Bóg jest wszechmocny w tym sensie, że może zrobić wszystko, gdyż biblijna koncepcja, potwierdzona zresztą w chrześcijańskim credo, mówi o Bogu Ojcu Wszechmogącym, stworzycielu nieba i ziemi. Warto zaznaczyć, że użycie zwrotu „wszechmogący” pada w kontekście zarówno ojcostwa Bożego, jak i w kontekście Boga Stworzyciela, który ma władzę panowania nad wszystkim, co istnieje i powstało dzięki aktowi stwórczemu. W tej perspektywie Bóg nie tyle jest wszechmocny (omnipotence) w sensie określenia granic tego, co może uczynić w świecie, ile raczej jest wszechmogący (almighty), czyli panujący nad całym stworzeniem, które od Niego pochodzi i jest całkowicie od Niego zależne. Pozwala to na uniknięcie trudności związanych ograniczaniem wszechmocy zarówno przez to, co jest możliwe logicznie, jak również przez to, co jest moralnie dopuszczalne. Bóg, który jest jednocześnie Stwórcą wszystkiego oraz kochającym Ojcem, $\mathrm{z}$ definicji nie będzie czynił w stworzeniu niczego, co będzie naruszało spójność i inteligibilność świata przez działania logicznie sprzeczne, lecz również nie będzie naruszał moralnej integralności w świecie poprzez wprowadzanie zamętu i niepewności wśród rozumnych stworzeń. Wydaje się zatem, że Geach podpowiada swoim rozróżnieniem pewną możliwość rozwiązania trudności moralnych granic wszechmocy, którą Kleszcz odrzuca z nie do końca zrozumiałych powodów.

\section{Dwie przestrogi}

Konkluzją obu tekstów Kleszcza poświęconych wszechmocy są dwie bardzo cenne przestrogi skierowane do tych, którzy skłanialiby się do różnych prób nadmiernego poszerzania pojęcia wszechmocy.

Pierwsza dotyczy ceny wiążącej się zawsze z takimi próbami, które $\mathrm{z}$ różnych powodów starają się poszerzyć możliwość działania dla wszechmocnego Boga. Kleszcz w tym kontekście przywołuje absolutyzację Bożej wszechmocy spotykaną w tekstach Stanisława Judyckiego ${ }^{12}$,

11 Por. (Geach 1977, s. 3-4).

12 Por. (Judycki 2010, s. 183-199). Absolutnej koncepcji wszechmocy Bożej, aczkolwiek z nieco innych powodów, broni również Dariusz Łukasiewicz (2014, s. 311-325). 
który dla zachowania pewnych teologicznych twierdzeń broni absolutnej wszechmocy pozbawionej jakichkolwiek ograniczeń. Niebezpieczeństwem takiego ujęcia jest przyznanie Bogu takich możliwości, które wymykają się jakiejkolwiek racjonalnej ocenie ze strony człowieka. Działania Boże stają się tym samym niezrozumiałe, a natura Boga pozwala na jednoczenie w sobie przeciwieństw i niezgodności, stając się czymś całkowicie tajemniczym i niezrozumiałym. Bóg chrześcijańskiego teizmu zaczyna niebezpiecznie przypominać absolutnie transcendentny byt czczony $\mathrm{w}$ islamie, do którego wolno nam tylko odnosić się z czcią i posłuszeństwem. Jak sugeruje Kleszcz, konieczną ceną rezygnacji z racjonalnego pojmowania Boga musi być zawsze jakaś forma teologii apofatycznej lub popadnięcie $\mathrm{w}$ irracjonalizm i zamęt. $\mathrm{Z}$ tego powodu najbezpieczniejszą drogą dla teizmu jest tradycja wiążąca Boga prawami logiki. Świat, w którym naruszona jest zasada sprzeczności, mógłby być światem niestabilnym bytowo i moralnie (egzystencjalnie). Byłby to świat irracjonalny, co narażałoby Boga na utratę czci - a to przemawia za ograniczeniem wszechmocy. Cena niepowiązania Boga z prawami logiki jest zbyt wysoka. Jeżeli istnieje pluralizm logiczny (za późnym Łukasiewiczem), to jego zwolennik powinien respektować jednak logikę niegenerującą sprzeczności, bo to pozwala na racjonalne rozważania o Bogu.

Druga uwaga dotyczy języka odnoszącego się do opisu natury i atrybutów Bożych, która nieco osłabia analityczne rozważania nad pojęciem wszechmocy. Mówiąc o językowych i poznawczych ograniczeniach w rozważaniach atrybutów Boga, Kleszcz przypomina, że trzeba zawsze pamiętać o pewnym fragmentaryzmie, a nawet o pewnej nieprzekraczalnej trudności w strukturach naszego języka, gdy odnosimy go do Boga. Dostępny nam język, pomimo że nie gwarantuje pełnej adekwatności, to jednak pozwala na zrozumienie czegoś o Bogu. Czy to oznacza, że logika wiąże Boga w sposób absolutny? Pewnie nie, ale pozwala na uniknięcie popadnięcia w irracjonalizm i sprzeczność, choć jest to zawsze nasz ludzki sposób mówienia i myślenia, i nasza racjonalność stosowana do rzeczywistości ostatecznej (Kleszcz 2012, s. 51-52). Dlatego Kleszcz z całym przekonaniem przypomina, że jeśli Boga nic by nie wiązało, to mógłby czynić rzeczy sprzeczne i wykonywać działania niespójne wewnętrznie oraz dokonywać rzeczy niegodnych i uwłaczających doskonałości przysługującej Bytowi Absolutnemu.

Na koniec trzeba koniecznie podkreślić, że oba analizowane teksty poświęcone wszechmocy są przykładem wysokich standardów rozważań z dziedziny filozofii. Kleszcz dał w nich próbkę tego, na czym powinna polegać rzetelnie uprawiana teologia filozoficzna. Jako wierny zwolennik tradycji Szkoły Lwowsko-Warszawskiej wyraźnie hołduje zasadzie Józefa Marii Bocheńskiego, która głosi, że „poza logiką jest tylko absurd”. 
Trzymając się tej zasady, wnosi jednak ożywczy powiew do tradycyjnej problematyki rozwijanej w filozofii religii. Jego rozważania nad atrybutami Bożymi, a zwłaszcza nad atrybutem Bożej wszechmocy, powoduja że staje się on klasycznym odnowicielem tej problematyki w filozofii polskiej. Można powiedzieć, że nie sposób już dzisiaj uprawiać w Polsce refleksji nad Bożą wszechmocą bez odwołania się do jego tekstów, które będą - jak sądzę - inspirować kolejne pokolenie polskich filozofów religii uprawiających teologię filozoficzną.

\section{Bibliografia}

Damiani P. (2008), O wszechmocy Bożej, Wydawnictwo Marek Derewecki, Kęty.

Frankfurt H. (2015), Logika wszechmocy, „Filo-Sofija” 30, s. 219-220.

Geach P. (1977), Omnipotence, [w:] idem, Providence and Evil, Cambridge University Press, Cambridge, s. 1-27.

Judycki S. (2010), Bóg i inne osoby. Próba z zakresu teologii filozoficznej, W Drodze, Kraków.

Kenny A. (1979), The God of the Philosophers, Clarendon Press, Oxford.

Kleszcz R. (1998), O racjonalności. Studium epistemologiczno-metodologiczne, Wydawnictwo Uniwersytetu Łódzkiego, Łódź.

Kleszcz R. (2007), O racjonalności i jej granicach, [w:] idem, O rozumie i wartościach, Wydawnictwo Wyższej Szkoły Humanistyczno-Ekonomicznej w Łodzi, Łódź, s. 9-31.

Kleszcz R. (2012), Logika, wszechmoc, Bóg, „Filo-Sofija” 19(4), s. 37-52.

Kleszcz R. (2015), O filozofii religii, wszechmocy Boga oraz ograniczoności naszego języka, „Filo-Sofija" 30, s. 199-214.

Łukasiewicz D. (2014), Opatrzność Boża, wolność, przypadek. Studium z analitycznej filozofii religii, W Drodze, Kraków.

Łukasiewicz J. (1961), Z zagadnień logiki i filozofii. Pisma wybrane, red. J. Słupecki, PWN, Warszawa.

Mavrodes G. (2015), Kilka łamigłówek dotyczacych wszechmocy, „Filo-Sofija” 30, s. 215-218.

Mordarski R. (2015), Granice omnipotencji, „Filo-Sofija” 30, s. 221-237.

Paluch M. (2008), Dystynkcja potentia absoluta - potentia ordinata, [w:] Św. Tomasz z Akwinu, Kwestie dyskutowane O mocy Boga, t. 1, M. Olszewski, M. Paluch (red.), Wydawnictwo Marek Derewecki, Kęty, s. 385-391.

Plantinga A. (1980), Does God have a Nature?, Marquette University Press, Milwaukee, Wisconsin.

Swinburne R. (1995), Spójność teizmu, Wydawnictwo Znak: Kraków.

Wade Savage C. (1997), Paradoks kamienia, [w:] B. Chwedeńczuk (red.), Filozofia religii, Wydawnictwo Spacja - Fundacja Aletheia, Warszawa, s. 183-189. 
Streszczenie: Wszechmoc i jej granice. Uwagi o koncepcji Bożej wszechmocy Ryszarda Kleszcza

Ryszard Kleszcz przedstawił interesującą interpretację Bożej wszechmocy, która wyrasta z silnej koncepcji racjonalności, mającej swój początek w programie Szkoły Lwowsko-Warszawskiej. Koncepcja ta koncentruje się na logicznych i moralnych problemach wszechmocy, podnosi kwestię paradoksów wszechmocy oraz zagadnienie możliwości zmiany przeszłości przez byt wszechmocny. W niniejszym tekście poddaję tę koncepcję krytycznej analizie i wskazuję na dalsze możliwości interpretacyjne, które umożliwia rozumienie wszechmocy zaprezentowane przez Kleszcza.

Słowa kluczowe: wszechmoc Boża, wszechmoc vs. logika, wszechmoc vs. wolność moralna, paradoksy wszechmocy, możliwość zmiany przeszłości, Ryszard Kleszcz

Summary: Omnipotence and its Limits. Comments on the Concept of Omnipotence of Ryszard Kleszcz

Ryszard Kleszcz presents an interesting interpretation of God's omnipotence, which arises from a strong concept of rationalism, which has its genesis in the program of the Lvov-Warsaw School. This concept concerns the logical and moral problems of omnipotence, addresses the paradoxes of omnipotence and the possibility of changing the past by an omnipotent being. In the text, I subject this concept to a critical analysis to show further possibilities in interpretation, which enables Kleszcz's understanding of omnipotence.

Keywords: omnipotence of God, omnipotence vs. logic, omnipotence vs. moral freedom, paradoxes of omnipotence, possibility of the changing the past, Ryszard Kleszcz 